\title{
Determinants of Foreign Direct Investment in Ethiopia: Systematic Review
}

\author{
Habtamu Legese (MSc.) \\ Head, Department of Economics, Raya University, Maichew, Ethiopia
}

\begin{abstract}
The determinants of FDI include any host country's situations that affects the inflow of FDI, like market size, the economic growth rate, real growth domestic product, infrastructure, natural resource, the political situation etc. In recent years, Ethiopia has started encouraging the inflow of FDI by improving the investment climate and by providing different incentive packages. The focus of this review is to identify the major determinants of foreign direct investment (FDI) in Ethiopia. The results show that the variables like real growth domestic product, liberalization, exchange rate devaluation and trade openness are significant and have positive correlation with the inflow of FDI in Ethiopia. On the other hand, variables like inflation, poor infrastructure; volatile and high lending interest rate has significant and negative association with the inflow of foreign direct investment. Finally, the study recommend possible intervention of the government through infrastructure development and formulation sound fiscal and monetary policies to control the negative impact of inflation, interest rate and other macro variables.
\end{abstract}

Keywords: FDI, RGDP, Inflation, liberalization, interest rate, Ethiopia.

DOI: $10.7176 / \mathrm{DCS} / 9-1-04$

\section{Introduction}

Ethiopia has managed to register double-digit economic growth over the past 13 years. This high growth has contributed to a sustained increase in per capita income and a decline in absolute poverty, as well as improvement in standards of living (MOFEC 2017). Investment is without doubt, one of the primary engines of development in all economies. Foreign direct investment (FDI) remains a significant source of capital and income generating opportunities for least developed countries. This is especially true for Ethiopia that does not have enough domestic funds to finance huge investment projects. It is also important for Ethiopia in transferring technological advancement for domestic enterprises, competitiveness and organizational forms, assist human capital formation, international trade integration and to create a more competitive business environment from abroad (Gelawdewos, 2015).

The need to meet the objective of faster economic growth and low level of capital accumulation are conflicting in nature. To solve this problem, FDI is served as a source of capital in most LDCs. (Getinet and Hirut 2006). FDI is particularly important for developing countries like Ethiopia since it provides access to resources that would otherwise be unavailable to these countries. Its contribution to economic development and therefore poverty reduction comes through its role as a conduit for transferring advanced technology and organizational forms to the host country, triggering technological and other spillovers to domestically owned enterprises, assisting human capital formation, contributing to international trade integration and helping to create a more competitive business environment. In short, FDI works as a means of incorporating under developed countries into the global market and improving capital availability for investment (Amanuel, 2014).

The rapid growth in FDI over the last few decades has initiated a large body of empirical literature to examine the determinants and the growth enhancing effects of FDI. Similarly, various studies have been conducted to identify the determinants of foreign direct in Ethiopia. . There is, however, absence of systematic review evidence on the determinants of foreign direct investment sources. The major objective of this work is, therefore, to review sample empirical studies conducted in Ethiopia and draw logical conclusion and recommendation. On the top of the above statement, this review is expected to provide convincing and significant information for concerning body such as government, policy makers, and other institutions working to promote foreign direct investment and hence to solve the problem of unemployment and balance of payment deficit of the country.

\section{Foreign direct investment (FDI) and related issues}

\subsection{The Benefits and Costs of FDI}

Understanding the benefits and the drawbacks of FDI is imperative to formulate a sound policy. Even if, in recent times, the policy that favors FDI dominates, there are two opposing views as to the role of FDI in developing economies. On the one hand, it is argued that FDI benefits the host country, for instance, by creating employment opportunities and bringing new technologies. In contrast, the other group argues that the adverse effects of FDI outweigh its benefits (Teshome, 2010). 


\subsection{Pro-FDI Views}

Economic growth depends on the general level of investment and investment in turn largely depends on savings. However, gross domestic savings are too low in the least developed countries (LDCs). As a result, foreign direct investment is the next best alternative source to fill the gap between domestic savings and the required investment for economic growth aweless economic development. Beside, foreign firms bring not only financial capital but also managerial techniques as well as, entrepreneurial and technological skills that lack in LDCs and these skills can be transferred to domestic firms through different channels. On the top of the above advantages, government's budget deficits can also be fixed by collecting profit-tax from transnational companies or from foreign direct investors (Todaro, 1992, Solomon 2008, Teshome 2010). FDI can also play important role by creating employment opportunities and by integrating the host-country economy in to the world economy (OECD, 2002).

\subsubsection{Anti-FDI Views}

On the other hand, a group of scholars strongly disagrees with the Pro- FDI views. Their first counter argument says that multinational corporations increase income for low-income groups, which have low propensity to save. If individuals do not save enough, the gap between savings and investments cannot be closed. Besides, foreign firms may also fail to reinvest the profit they generate in the host country; hamper the growth of domestic enterprises and domestic investment by importing the input and intermediate product from their subsidiaries in other countries. FDI might also inhibit the development of indigenous skills as the result of multinational companies' dominance over local enterprises (Todaro, 1992, Solomon 2008, Teshome 2010).

It is expected that government's budget deficits can also be fixed by collecting profit-tax from transnational companies or from foreign direct investors. However, governments often enter in to exclusive agreements with foreign firms and provide tax holidays, tariff protections, and investment allowances (this is common here in Ethiopia). Due to these reasons, the taxes that can be collected will not be up to the required level or becomes quite small. Moreover, most of the time foreign direct investors participates in tax avoidance and tax evasion practices. For example, these firms can avoid local taxation by transfer pricing techniques -a method used to reduce local profit level by paying artificially inflated prices to the intermediate products purchased from abroad subsidiaries (Thomas A. and Peter H. 2000).

\subsection{The motives for foreign direct investment}

Researchers conducted on the issue indicates the three possible motives for FDI by referring Dunning (1993) as cited on Amanuel , 2014; Getinet and Hirut 2006; Rozina 2016 ; Haregewoyn 2016 , Henok ,20 14 and Gelawdewos , 2015 and according to those researches, FDI has the following three broad purposes.

Market seeking or (horizontal) FDI: In this case, the main aim of FDI is to provide goods and service to local and district market. The motive for horizontal FDI is market size and market growth. The investors who are seeking market size for investment need to have host countries, which have a large market size, high potential of market growth and high per capital income.

Resource (asset seeking) FDI: This type of FDI is carried out when the investing firm's aim is to get access to the resources in the host country which are not obtainable in home country. Examples of these resources are natural resources, raw materials or low cost labor.

\section{Efficiency seeking FDI}

Under this type of foreign direct investment the investor will invest to get an advantage when there is a common governance of geographically dispersed activities, especially in the presence of economies of scope and scale and diversification of risk.

The above three motives of FDI are categorized under economic determinants of FDI. Besides these economic determinants, there are also two other crucial determinants of FDI: which is the hosting country FDI policy framework and business facilitation (Getinet and Hirut 2006).

\section{Foreign direct investment in Ethiopia}

The government of Ethiopia has established the Ethiopian Investment Authority (EIA) in the year 1992 to promote, coordinate and facilitate foreign investment in the country. Functions of EIA, among others, include; providing all the necessary information required by foreign investors, approving foreign investment applications, issuing investment permits, registration services, approving expatriate posts in approved investments and issuing work permits to foreign employees. Issuing trade and operating licenses for foreign investments, monitoring the implantation of licensed investment projects, approving and registering technology transfer agreements between local companies and foreign technology suppliers, and facilitating the acquisition of land by foreign investors in accordance with the relevant federal and regional government laws and regulations (Getinet and Hirut ,2006; Solomon , 2008 ; and Henok, 2014 ). 
Figure 1: Sectoral distribution by no of projects (1992-2016)

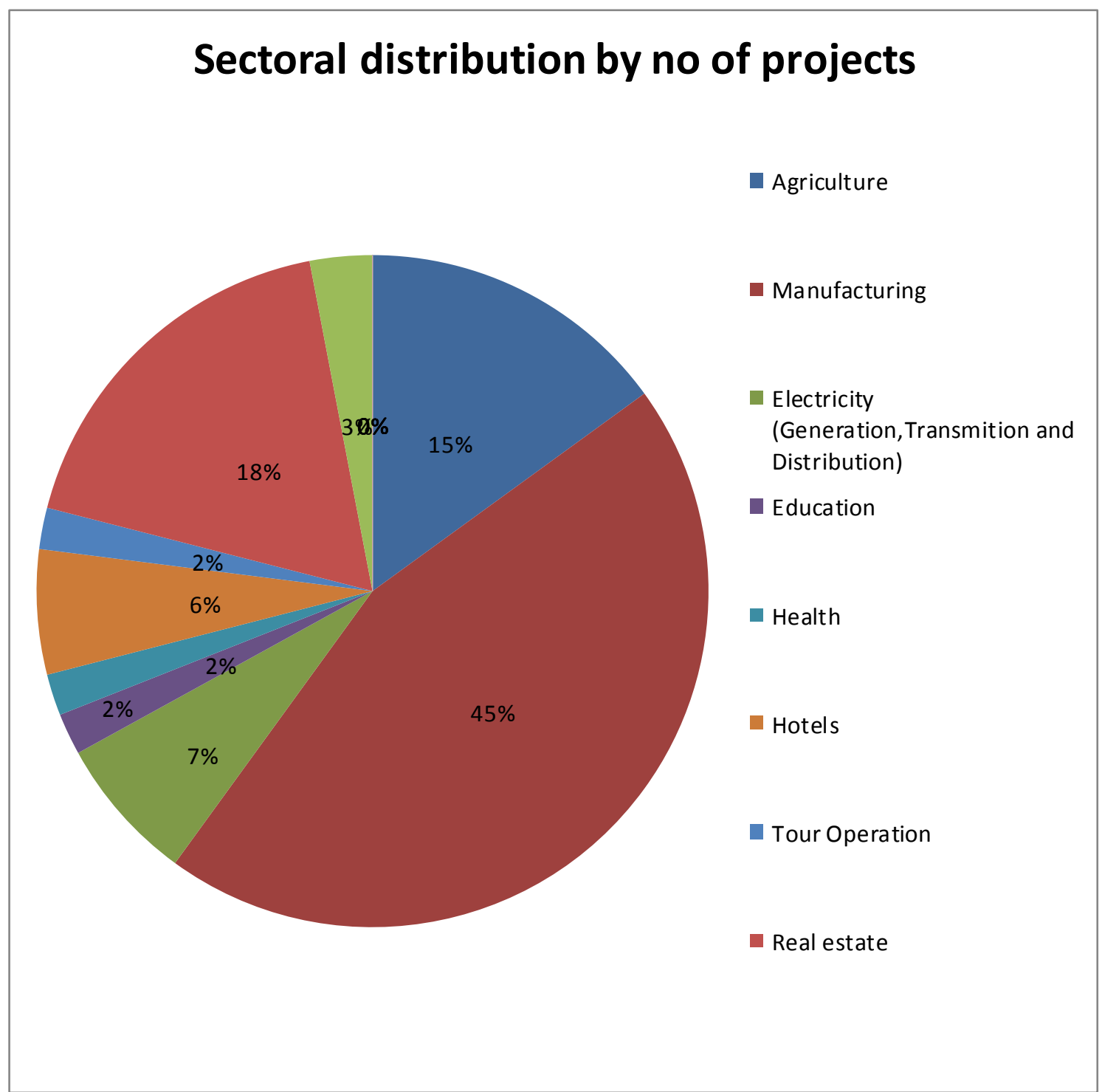

Source: Ethiopian investment commission (EIC), 2017

According to the EIA, the areas with the most promising potential for investment are agriculture, agroprocessing, textiles and garment, leather and leather products, tourism, mining, and hydropower (Amanuel Mekonnen 2014). Ethiopian Investment Commission recently announced that the country's FDI increased by 35 percent on average over the first last six months of the fiscal year 2016/17 compared to same period of $2015 / 2016$. FDI flows to the country continued to show positive track of record in 2016/17 despite the recent unrest occurred in some parts of the country (MOFC 2017).

Table 1 and Figure 2: Foreign direct investment inflow (in US\$ millions) 2007 - 2017

\begin{tabular}{lllllllllll}
\hline Year & $\mathbf{2 0 0 7 / 0 8}$ & $\mathbf{2 0 0 8} / \mathbf{0 9}$ & $\mathbf{2 0 0 9} / \mathbf{1 0}$ & $\mathbf{2 0 1 0} / \mathbf{1 1}$ & $\mathbf{2 0 1 1} / \mathbf{1 2}$ & $\mathbf{2 0 1 2} / \mathbf{1 3}$ & $\mathbf{2 0 1 3} / \mathbf{1 4}$ & $\mathbf{2 0 1 4} / \mathbf{1 5}$ & $\mathbf{2 0 1 5} / \mathbf{1 6}$ & $\mathbf{2 0 1 6} / \mathbf{1 7}$ \\
\hline Total FDI & 814.6 & 893.7 & 960.3 & $1,242.5$ & $1,072.1$ & $1,231.6$ & $1,467.0$ & $2,202.2$ & $3,268.7$ & $4,170.8$ \\
\hline
\end{tabular}




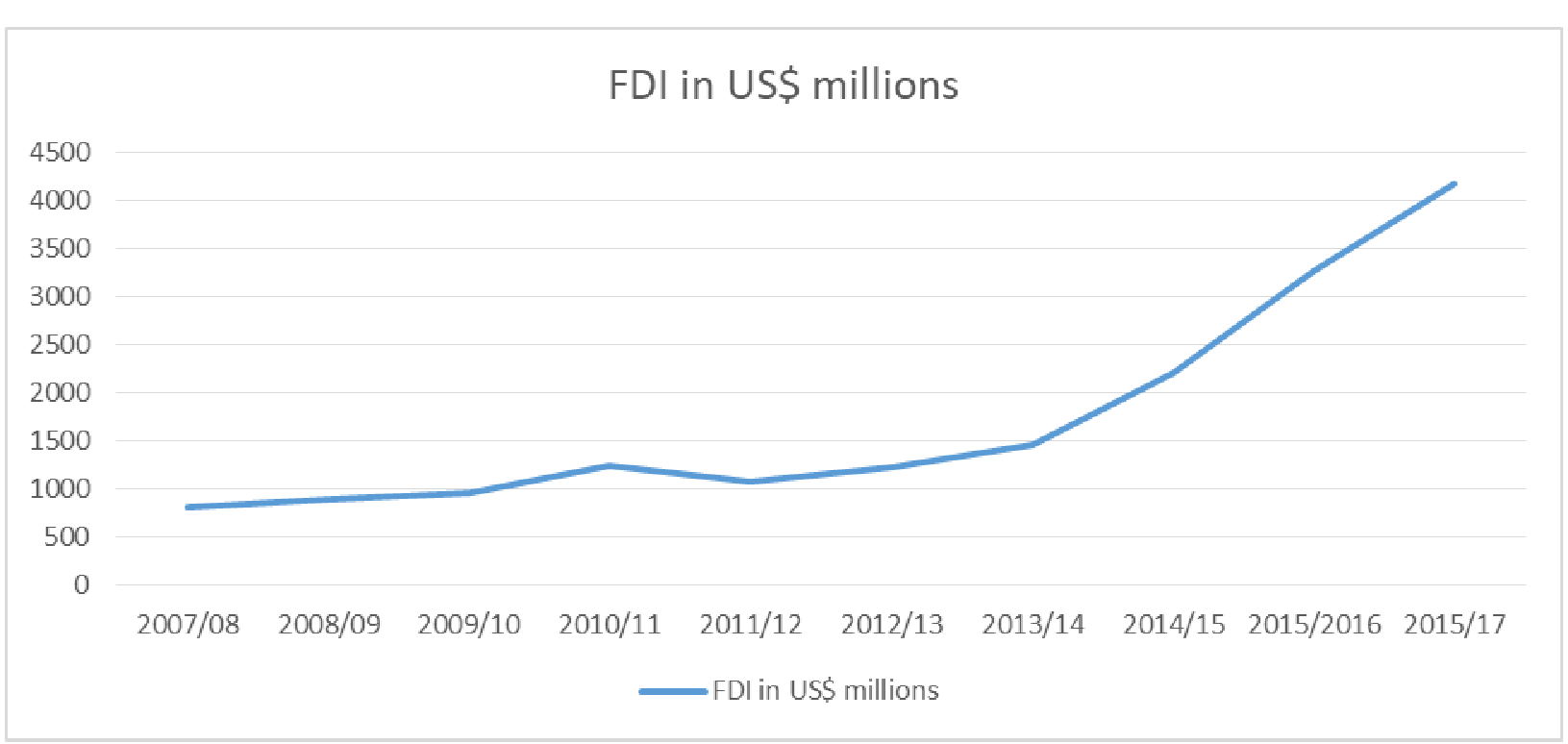

Source: Ethiopian investment commission (EIC), 2017

\subsection{Prospective of FDI in Ethiopia}

Ethiopia has recorded annual average GDP growth of about ten percent in the last decade, driven by public investments in agriculture and infrastructure. The poverty rate has fallen from 44 percent in 2000 to 23.5 percent in 2015/16. In 2016/17 GDP growth is estimated at 9 percent, as agriculture rebounded from severe drought conditions in 2015/16. Industrial activity expanded, with continued investments in infrastructure and manufacturing. The current account deficit declined in 2016/17 to 8.2 percent of GDP from 9.1 percent the previous year, reflecting lower drought-related imports and lower public sector capital goods imports. However, export revenues were largely unchanged despite significant volume growth, as global agricultural commodity prices remained low. Foreign direct investment (FDI) growth was 27.6 percent due to investments in the new industrial parks and privatization inflows. International reserves at end-2016/17 stood at US\$3.2 billion (1.8 months of prospective imports cover). (IMF, 2018)

The government of Ethiopia follows integrated 5-year plans to guide its state-led industrial development. The second of these Growth and Transformation Plans (GTP II), covering 2016-2020, is now being implemented. GTP II sets a target of an average growth of $11 \%$ in the next five years with the objective of middle income status by 2025 . To realize these goals, the government continues to pursue consistent and prudent macroeconomic policies and to invest heavily in large-scale social, infrastructural and energy projects. Included in the GTP II are incentives for international investors, such as facilitation of repatriation of investment and profit, ease in hiring expatriate personnel, temporary income tax exemptions for investments in selected sectors, duty-free imports of capital goods, components and raw materials for exporting industries and manufacturers in priority sectors (Cole, 2017 Cited by Tesfaye 2017).

Politically, the country is one of the most stable country in the horn of Africa. Economically, in order to enhance the export sector, the government has established the Ethiopian commodity exchange (ECX). In addition to this, the rural development policy and strategy is under implementation, underlines that AgriculturalLed development will bring about fast economic growth, enable its people become beneficiary of economic growth, and lay solid foundation for the industrial development. To utilize the enormous potential for hydropower energy, the country is running renewable mega hydropower plants across the country. Priority is given to road transport infrastructure development, because it's playing a vital role on transporting goods in Ethiopia. In addition to the road transport, to sustain the rapid economic growth, it requires availability of railway network. Therefore, the government is constructing a total of $2395 \mathrm{~km}$ of national railway network. The old railway connects Addis Ababa to Djibouti being replaced by electrified railway, expected to boost Ethiopia's import-export trade. The reputable Ethiopian airline is also playing its role on providing cargo services worldwide. 18 financial institutions and insurance companies are operating in the country. The government also offer different tax holidays or exemptions which ranges from 2-10 years depending on the nature of investment (Tesfaye, 2017).

On the top of the above incentives the Ethiopia government has a bilateral agreement investment promotion and protection with following countries; Algeria, Austria, Belgium \& Luxemburg, China, Denmark, Egypt, Equatorial guinea, Finland, France, Germany, India, Iran, Israel, Italy, Republic of Djibouti, Qatar, Kuwait, Libya, Malaysia, Netherlands, Russian federation, South Africa, Spain, Sudan, Sweden, Switzerland, Tunisia, Turkey, UK, USA and Yemen. In addition, the country has signed double taxation avoidance treaties 
with; Czech Republic, France, Israel, Italy, Kuwait, Romania, Russia, South Africa,, Tunisia, Turkey, and Yemen ( EIC 2014).

However, there are a number of obstacles to invest in Ethiopia. Mainly by the following principal obstacles that foreign enterprises face in Ethiopia: Trade regulation and customs clearance efficiency. Perceived foreign exchange rate risks deter investment. Restrictions on foreign currency transaction and conversion, in combination with perceived uncertainty over the foreign exchange rate path, tax administration inconsistency and inefficiency ( more than 70 percent of the surveyed firms find the inconsistency of tax law explanation and the frequent law amendment a major obstacle to doing business), Insufficient local access to finance. Ethiopia is also known by nationalizing lucrative business. For example, telecommunication, airlines, shipping, hydropower plants belong to the government and foreign investors not allowed to possess these businesses. Additionally, the financial sector is open only for Ethiopians. The other problem face foreign investors is culture of the community. Other obstacles were corruption, infrastructure (Tesfaye, 2017).

\section{METHODOLOGY OF THE STUDY}

This study based systematic review involved descriptive analysis. The primary data were systematically collected from 6 (six) quantitative studies and from 2 (two) qualitative studies conducted in Ethiopia between 2006 and 2017. On the top of the above researches, the author also used a number of supportive researches, which is conducted in the aforementioned issues. The study used descriptive statistics (like frequency distribution tables) to analyze the demand side, supply side and mainly the macroeconomic factors affecting the inflow of foreign direct investment in Ethiopia.

This review employed two-stage screening stages, which is title and abstract screening and Full-text screening. The researcher used hand-searching method with key search terms from internet. Various papers were identified with the same topic. Of these paper 6 (Six) studies were found relevant for the review. The study assumed that dependent variable (Foreign direct investment FDI)) is a function of various economic variables. For this study, however, the main determinants of foreign direct investments are real growth domestic product (RGDP), Inflation (Inf), Poor Infrastructure (PInfra), Interest rate (I), liberalization (L), Exchange rate (Er) and Trade openness (To).

\section{Real growth domestic product (RGDP)}

Investment is the dynamic element of Gross Domestic Product (GDP), the only one that allows domestic production to increases and with it employment. It influences the consumer and government spending, the latter through increased tax revenues (Carlos and Eddie, 2015). On the other hand real growth domestic product have also a power to attract foreign direct investors.

\section{Inflation and Exchange rate}

When a country's currency devalues, it is viewed as an opportunity for foreign investors to purchase assets at a reduced cost. This is especially true when foreign firms have identified specific assets in their targeted markets (Blonigen, 1997). Frequent and erratic changes in exchange rate of the domestic currency affect the inflow of FDI (Goldberg and Klien, 1997). Barrell and Pain (1996) find that investors tend to postpone their investment when the currency in the targeted market strengthens.

Through its effect on the cost of inputs and the price of outputs, inflation reduces the real return on investment and firms' competitiveness. Hence, countries that pursue policies that reduce inflation rate have better chance in attracting FDI. Low and predictable inflation rate is central for the long-term investment of both domestic and foreign companies. Therefore, higher and unpredictable inflation will decrease the inflow of FDI (Birhanu, 1998). Generally, Inflation rates and exchange rates are used as proxy variables for macroeconomic stability. Low inflation and stable exchange rates are expected to have a positive impact on FDI (Teshome, 2010).

\section{Poor Infrastructure (P Infra)}

Infrastructure covers many dimensions ranging from roads, ports, railways and telecommunication systems to the level of institutional development (Getinet and Hirut 2006; Amanuel, 2014). The availability of well developed infrastructure will reduce the cost of doing business for foreign investors and enable them to maximize the rate of return on investment (Morriset, 2001). Therefore countries with good infrastructures are expected to attract more FDI. Gross fixed capital formation (percent of GDP) has been included to proxy infrastructure development. FDI is expected to have positive relationship with infrastructure of the host countries. (Amanuel, 2014)

\section{Interest rate (I)}

Interest rate is the amount of money charged by a lender to a borrower. It is often expressed as a percentage of the principal amount (Benson, 2016). Interest rates will be adjusted to reflect changes in inflation. As a result, interest rates are critical determinants of foreign direct investment. Defines interest rate as the cost of borrowing capital and also a measure of return on investment. Traditionally, investors will shop for low cost credit sources or lower interest rates and invest it in economies that are promising higher returns (Singhania, 2011).. 
Trade Liberalization (L)

There are reasons to expect that different kinds of trade would influence FDI flows differently. While trade associated with cross-border vertical integration may boost FDI by providing incentives of cost reduction, intraindustry trade may discourage FDI that seeks economies of scale ( Bishwanath and Rashmi, 2007). Liberalization of trade and FDI regimes are assumed to have a positive influence on the inflow of FDI since they facilitate a freer trade and investment in conjunction with the repatriation of dividends and profits to home countries (Bende , 2002, cited by Teshome 2010 ). Ethiopia has been introducing some liberalization measures since 1991 and researches, which include this variable, used a dummy variable to capture the effect of the change in policy environment on FDI. The dummy variable assumes a value of 0 for the pre-liberalization period (i.e. up to 1990) and 1 for the post liberalization period (from 1991 onwards).

Trade Openness: Trade openness promotes FDI and it is measured as the ratio of export to GDP. Sign and Jun's 1995 study indicates that exports, particularly manufacturing exports are a significant determinants of FDI inflow and the test shows that there is a strong evidence that exports precede FDI flows.

\section{Result, Conclusion and Policy Recommendation}

\subsection{Description of Reviewed Literatures}

In this section of the study, the reviewer present some of the general characteristics of literatures in terms of title, nature of data, and periods under study.

Table 2: Summary of Reviewed Studies

\begin{tabular}{|c|c|c|c|c|}
\hline No. & Authors & Title & Type of Data & Years \\
\hline 1 & $\begin{array}{l}\text { Rozina } \\
(2016)\end{array}$ & $\begin{array}{l}\text { Determinants of Foreign } \\
\text { Direct Investment In Ethiopia: } \\
\text { Time Series Analysis }\end{array}$ & $\begin{array}{l}\text { Time-Series } \\
\text { (Annual) }\end{array}$ & $\begin{array}{l}1981- \\
2014\end{array}$ \\
\hline 2 & $\begin{array}{l}\text { Haregewoyn } \\
(2016)\end{array}$ & $\begin{array}{l}\text { Determinants of Foreign Direct Investment: Evidence } \\
\text { from Ethiopia }\end{array}$ & $\begin{array}{l}\text { Time Series } \\
\text { (Annual) }\end{array}$ & $\begin{array}{l}1975- \\
2014\end{array}$ \\
\hline 3 & $\begin{array}{l}\text { Gelawdewos } \\
\text { (2015) }\end{array}$ & $\begin{array}{l}\text { The Determinants Of Foreign Direct Investment (FDI) } \\
\text { In Ethiopia }\end{array}$ & $\begin{array}{l}\text { Time Series } \\
\text { (Annual) }\end{array}$ & $\begin{array}{l}1980- \\
2014\end{array}$ \\
\hline 4 & Teshome (2010) & $\begin{array}{l}\text { Determinants Of Foreign } \\
\text { Direct Investment In Ethiopia }\end{array}$ & $\begin{array}{l}\text { Time Series } \\
\text { (Annual) }\end{array}$ & $\begin{array}{l}1981- \\
2007\end{array}$ \\
\hline 5 & Amanuel (2014) & $\begin{array}{l}\text { Factors Affecting FDI Flow In Ethiopia: An Empirical } \\
\text { Investigation }\end{array}$ & $\begin{array}{l}\text { Time Series } \\
\text { (Annual) }\end{array}$ & $\begin{array}{l}1990- \\
2011\end{array}$ \\
\hline 6 & $\begin{array}{l}\text { Getinet \& Hirut } \\
(2006)\end{array}$ & $\begin{array}{l}\text { Determinants of Foreign Direct Investment in Ethiopia: } \\
\text { a time series analysis }\end{array}$ & $\begin{array}{l}\text { Time-Series } \\
\text { (Annual) }\end{array}$ & $\begin{array}{l}1974 \\
2001\end{array}$ \\
\hline 7. & Tesfaye (2017) & $\begin{array}{l}\text { Foreign Direct Investment (FDI) Outlook in Ethiopia: } \\
\text { An Evidence from Oromia Region Selected Special } \\
\text { Zones }\end{array}$ & $\begin{array}{l}\text { Descriptive } \\
\text { statistics }\end{array}$ & 2017 \\
\hline 8. & Henok (2014) & $\begin{array}{l}\text { Determinants and Impediments of FDI } \\
\text { inflows in Ethiopia- A Firm } \\
\text { Investigation }\end{array}$ & $\begin{array}{l}\text { Descriptive } \\
\text { statistics }\end{array}$ & 2014 \\
\hline
\end{tabular}

Source: Reviewed literatures 2018

This study, however, focused on determinants of foreign direct investment in Ethiopia. The sign (S) shows that the variable has been found significant from reviewed literatures and the $( \pm)$ shows the impact of a variable. Table 3: Determinants of Economic Growth

\begin{tabular}{|c|c|c|c|c|c|c|c|c|}
\hline \multirow[t]{2}{*}{ No. } & \multirow[t]{2}{*}{ Authors } & \multicolumn{7}{|c|}{ Variables } \\
\hline & & RGDP & INF & PINFRA & I & $\mathbf{L}$ & Er & To \\
\hline 1 & Rozina & $\mathbf{S ~ ( + ) ~}$ & S (-) & S (-) & & S (+) & & \\
\hline 2 & Haregewoyn & & & & S (-) & S (+) & S (+) & S (+) \\
\hline 3 & Gelawdewos & $\mathbf{S ~ ( + )}$ & S (-) & & S (-) & & & \\
\hline 4 & Teshome & S (+) & S (-) & S (-) & & & & S (+) \\
\hline 5 & Amanuel & & S (-) & & & & & S (+) \\
\hline 6 & Getinet \& Hirut & $\mathbf{S ~ ( + )}$ & S (-) & S (-) & & S (+) & & \\
\hline
\end{tabular}

Source: Reviewed literatures 2018

According to the above table, the independent variable real growth domestic product have positive impact on foreign direct investment (FDI) inflow to Ethiopia (Rozina, 2016; Gelawdewos, 2015; Teshome, 2010; Getinet \& Hirut, 2006). On the other hand, one of the major macroeconomic variable 'inflation' is negatively associated with the inflow of FDI (Rozina, 2016; Gelawdewos, 2015; Amanuel 2014; Teshome, 2010; Getinet \& Hirut, 2006). According to the regression, poor infrastructure prevails its negative impact on the inflow of FDI (Rozina, 2016; Teshome, 2010; Getinet \& Hirut, 2006). Similarly, interest rate have also significant and negative 
impact on the inflows of FDI (Gelawdewos, 2015 and Haregewoyn, 2016). When we see the relation between trade liberalization and inflows of FDI there significant and positive correlation as indicated in the researches of Rozina, 2016; Haregewoyn, 2016 and Getinet \& Hirut, 2006. With reference to the exchange rate as the government of home country devaluate its currency there is possibility to attract foreign direct investors (Haregewoyn, 2016). The last variable, considered within this review is trade openness. According to the findings of Haregewoyn, 2016; Amanuel 2014 and Teshome, 2010 trade openness has significant and positive impact on the inflows of FDI to the home country.

Tesfaye, 2017 and Henok, 2014 also made a descriptive analysis on the factors affecting the FDI in Ethiopia. Their findings reviled that Ethiopia relatively stable in macro economy, secure and safe in the horn of Africa (political and social stability ), strategic geographic location with favorable climate, inexpensive, sufficient labor, potentiality on the local market, government incentives, and consistent economic growth and regional market opportunity are the main drivers of FDI to Ethiopia. On the other hand, the major obstacles or challenges that constrain the inflows of FDI are trade regulation and custom clearance (and lack of clear policies and regulatory impediments), shortage of foreign exchange and rate volatility, tax administration inconsistency and inefficiency, insufficient local access to finance, openness of business and culture (Tesfaye, 2017).

\subsection{Conclusion and Recommendations}

FDI is an important source of investment in an economy. Performance of a host country in terms of GDP is important for investors in an economy however, the country must do more to improve its GDP (Benson, 2016). Currently most developing countries are trying to attract foreign direct investor and Ethiopia as nation with low domestic saving and with high budget deficit needs to be the part of this competition. This study aims to carefully review sample empirical studies conducted in Ethiopia to identify factors that determine the inflow of FDI in Ethiopia. As it is stated in the methodology part review applied, two stage screening process: title and abstract screening and Full-text screening.

Real growth domestic product, liberalization and trade openness are among the major determinants of FDI, which affect the inflow of FDI positively. On the other hand, variables like inflation, poor infrastructure, level of interest rate negatively related with the inflow of FDI.

Based on the reviewed literatures, the study recommends that in order to sustain and improve the inflows of foreign direct investment (FDI) the Ethiopian government and other concerned body first should focus on factors that hinder domestic investments. Because, foreign investors will be encouraged to invest in a country if the domestic investors are doing successfully. The positive and significant effect of economic growth on FDI indicates the decisiveness of economic growth in stimulating investment by foreign as well as domestic investors. As result, its must to keep up the growth momentum and ascertaining its sustainability is a key to increase the inflow of FDI.

The negative and significant impact of inflation indicates the importance of a more focused macroeconomic policy environment that supports the economy and builds confidence for potential investors. Necessary steps have to be taken to contain inflation and stabilize exchange rate through the adoption of sound fiscal and monetary policies. Otherwise, we may face outflow of FDI. Similarly, poor infrastructure have also a negative impact of the inflow of FDI. Government should therefore invest more in infrastructure because it is essential for the creation of a productive business environment

The significantly positive effect of liberalization on FDI indicates that an efficient environment that comes with liberalized economy is likely to attract foreign investors. Until now, a number of policies has been realized about liberalization but still further measures aimed at encouraging privatization. Besides, the government of Ethiopia should also work by giving priority to stabilizing the political environment, ensuring peace and security to citizens.

\section{Author details}

Habtamu Legese (MSc.)

Head, Department of Economics, College of Business and Economics, Raya University, Maichew, Ethiopia

\section{REFERENCES}

Amanuel Mekonnen (2014). Factors Affecting FDI Flow in Ethiopia: An Empirical Investigation. National Graduate Institute for Policy Studies (GRIPS) 7-22-1 Roppongi, Minato-ku | Tokyo 106-8677 | Japan

Barrell, R. and Pain, N (1996). An econometric analysis of U.S. foreign direct investment. The Review of Economics and Statistics, 78(2), 200-207.

Bende-Nabende, A. (2000). Foreign direct investment determinants in Sub-Sahara Africa: A co-integration analysis. Economics Bulletin, Vol.6, No.4, 1-19.

Benson Kiplagat (2016). The Effects of Interest Rates on Foreign Direct Investments in Kenya. A research project submitted in partial fulfilment of the requirements for the award of the degree of master of business 
administration (mba), School of Business, University of Nairobi.

Berhanu Nega (1998).Domestic Industry and International Competition ( In Amharic ), In Alemayehu Geda( ed.). Ec onomic Focus Vol. 1, no.3

Blonigen, B.A (1997). Frim-specific assets and the link between exchange rates and foreign direct investment. The American Economic Review, 87(3), 447-465.

Carlos and Eddie (2015). Foreign direct investment and gross domestic product growth. International Conference on Applied Economics, ICOAE 2015, 2-4 July 2015, Kazan, Russia.Procedia Economics and Finance 24 ( 2015 ) $198-207$.

Cole, T. (2017, May 02). Ethiopia: Investment Climate Statements. Retrieved from www.state.gov: https://www.state.gov/e/eb/rls/othr/ics/2016/af/254197.htm

EIC ( 2014) . Ethiopia : Prefered Location for Foreign Direct Investment in Africa. Ethiopian Investment Commission, 2014 . Addis Ababa, Ethiopia.

EIC (2017). Ethiopian Investment Report. Ethiopian Investment Commission. Addis Ababa, Ethiopia.

Erramilli, and D'Souza (1995). Uncertainty and foreign direct investment: the role of moderators. International Marketing Review, 12(3), 47-60.

Gelawdewos Aweke (2015). The Determinants of Foreign Direct Investment (FDI) In Ethiopia (A Time Series Analysis). A Senior Essay Submitted To the Department Of Economics in Partial Fulfillment of the Requirement for Degree Of Bachelor of Arts In Economics, Addis Ababa, Ethiopia.

Getenet Astatike and Hirut Assefa (2006.) Determinants of Foreign Direct Investment in Ethiopia: A time Series Analysis. London: Policy Studies Institute.

Goldberg, Linda S. and Kelin Michaeal (1997). Foreign Direct Investment, Trade and Real Exchange Rate Linkages in South East Asia and Latin America. NBER Working Paper No.6344. Massachusetts, USA.

Haregewoyn Deyu (2016). Determinants of Foreign Direct Investment: Evidence fromEthiopia. Journal of Poverty, Investment and Development. Vol.25, 2016

Henok Gebremedhin (2014). Determinants and Impediments of FDI inflows in Ethiopia - A Firm LevelInvestigation. Universita Catholica Del Sacrou Cureo (UCSC), ASERI (Postgraduate School of Economics and International Relations), Milan-Italy

IMF (2018). The Federal Democratic Republic Of Ethiopia. Staff Report For The 2017 Article Iv Consultation-Press Release; Staff Report;And Statement By The Executive Director For The Federal Democratic Republic Of Ethiopia. IMF Country Report No. 18/18

MOFEC (2017). A Note on Developments of Foreign Direct Investment in Ethiopia. Fiscal Policy Directorate of Ministry of Finance and Economic Cooperation. Fiscal Report Series No. 001/2017

Morisset, J. (2001). Foreign Direct Investment in Africa: Policies Also matter, Transnational Corporation, 9(2), $107-125$

OECD. (2002). Foreign Direct investment for development: maximize benefit and minimize cost. Paris: OECD Publications Service.

Rozina Tewelde (2016). Determinants of ForeignDirect Investment in Ethiopia:Time Series Analysis. Submitted to the Department of Economics, Indra Gandhi National OpenUniversity in partial fulfillment of the requirements for a Master of Art Degree in Economics. Indra Gandhi National Open University.

Singh, Harinder and Jun, Kwang W. (1995). Some New Evidence on Determinants of Foreign Direct Investment in Developing Countries. The World Bank Policy Research Working Paper, No, 1531

Singhania, Monica, \& Akshay (2011).Determinants of Foreign Direct Investment in India. Journal of International Trade Law and Policy 10, no. 1 (2011): 64-82.

Solomon Mamo (2008). Determinants of Foreign Direct Investment in Ethiopia. Thesis submitted to Maastricht School of Governance in partial fulfillment of the requirements for the degree of Master of Science in Public Policy. Maastricht, The Netherlands.

Teshome Gebre (2010). Determinants of Foreign Direct Investment in Ethiopia. A Senior Essay submitted to Department of Economics of Arbaminch University in Partial Fulfillment of the Requirement of Bachelor of Arts Degree in Economics Arba Minch, Ethiopia.

Thomas A. Pugel and Peter H. Lindert (2000).International Economics (11th edition). USA:

Todaro, Michael P. (1992).Economics for developing world (3rd Ed.). New Delhi: Longman 